Article

\title{
Bridging Discussions of Human History: Ancestry DNA and New Roles for Africana Studies
}

\author{
Bessie L. Lawton *, Anita Foeman and Nicholas Surdel \\ Department of Communication Studies, West Chester University, West Chester, PA 19383, USA; \\ afoeman@wcupa.edu (A.F.); nsurdel@ufl.edu (N.S.) \\ * Correspondence: blawton@wcupa.edu; Tel.: +1-610-436-2500
}

Received: 16 December 2017; Accepted: 17 January 2018; Published: 22 January 2018

\begin{abstract}
This paper explores how Africana Studies offer the opportunity for a new worldview that may supplant the assumption that Western history is history. It considers how new knowledge of the human migration bodes for the future of Africana Studies. It has the following research questions: (1) Does new ancestry data reveal or clarify African narratives that may have been missing or suppressed?; (2) What heritage do participants over- or under-predict?; (3) Do participants over-predict indigenous American heritage?; and (4) How is unexpected heritage received? Data from the DNA Discussion Project is used to answer these questions, and implications for bridging discussions of human history using Ancestry DNA are discussed.
\end{abstract}

Keywords: DNA; race; identity; Africana Studies

\section{Introduction}

In Siddhartha Mukherjee's book The Gene (2016), the oncologist, physician, and Pulitzer prize-winning author explores how the gene-the basic unit of heredity-has been viewed in extremes in arguments regarding its link to human identity. Mukherjee writes, "The Nazis were as obsessed with the fixity of identity as the Soviets were with its complete pliability." However, in both cases, he posits, "By appropriating the language of genes and inheritance, entire systems of power and statehood were justified and reinforced (Mukherjee 2016, pp. 127-28)." Of course, even prior to the discovery of the nature of heredity, slave traders (as others before them) used the idea of lineage to justify structures of power and oppression regarding "'race', a poor surrogate for nearly any feature." (Mukherjee 2016, p. 342).

The goal of this paper is to explore how Africana Studies offer the opportunity for a new worldview that may supplant the assumption that Western history is history. This examination addresses the challenge of broadening the view of Africana Studies while maintaining the uniqueness and original intent of these programs. This view centralizes Africana Studies, which can more faithfully and evenly reflect the human saga. Further, it acknowledges the centrality of culture and history over genetic determinism, using genetics in a nuanced way to unearth human history and explore identity rather than to rigidly predict, direct, or limit human activities. It places Africana Studies in the position to lead the conversation regarding the complex nature and origins of the human experience.

We will first place this paper in the context of the larger, ongoing DNA Discussion research program. We then explain the methods employed. Next, we present research findings, and finally consider what this all means to the evolution of Africana Studies.

\section{The DNA Discussion Project}

Over the past decade, Foeman and later Foeman, Lawton, and Rieger (Foeman 2009, 2012, 2013; Foeman et al. 2014; Lawton and Foeman 2017) have identified patterns of response to new ancestry DNA data. In particular, Foeman (2009) discussed how African Americans find ancestry data to be 
a "gift" that helps them fill in blanks in their cultural background and verifies cultural lore, which is a source of affirmation. It confirms the fact that human life began in Africa, which is a source of pride. It also aids in pinpointing other ancestry influences from Asia, Europe, indigenous people, etc., shedding light on traditions, phenotypes, and genetics that formally had little context in the Black narrative. This provides a sense of global citizenship and new insight into the African diaspora, which has been suppressed by a long history of racism and hypodescent (the practice of classifying a child of mixed race ancestry in the more socially subordinate parental race) in the USA and beyond (Ho et al. 2017; Craig and Richeson 2012; Peery and Bodenhausen 2008; Girard 2010).

Disparagement of African ancestry and hypodescent worked to present Black people as unidimensional and negative. Foeman, Lawton, and Rieger (Foeman et al. 2014) and Lawton and Foeman (2017) found that people who do not identify specifically as Black have few narratives that include African ancestry. On the other hand, both Whites and Blacks share stories that tend to overestimate indigenous American ancestry. It is noteworthy that those who examine the relationship between ancestry DNA and identity argue that people have irrationally romantic notions of indigenous ancestry and may want to claim it as their own. This may work particularly well as an alternative to negative narratives of White/Black mixing. TallBear (2013), Golbeck and Roth (2013), and Bader and Malhi (2015) view Native claims (even those based on DNA) with suspicion.

The DNA Discussion Project's findings support the notion that culturally, narratives function less to advance the "truth," but rather to give the most advantageous plausible explanation of one's circumstances (Fisher 1985; Stone 1988). DNA now provides one additional factor that must be managed in creating an authentic-sounding narrative. Thus, it is not surprising that people who identify as Black or Latinx are more likely to predict a multiracial ancestry in a pretest survey. They predict indigenous, African, European, and other lineages. Whites, on the other hand, tended to predict that that they were 99 or $100 \%$ European, systematically overestimating their "whiteness". Foeman, Lawton, and Rieger (Foeman et al. 2014) propose that this is because Whites already have the most advantageous narrative and will likely experience only loss in its dilution. Romantic narratives of a Native ancestry and a photo of a great, great ... grandmother with "a long dark braid" can explain away other elements. Although attitudes toward race are changing in a multicultural world (Hochschild et al. 2012), Whites remain least likely to retain stories of "the other".

Africana Studies have always existed to advocate for education, dignity, diversity, and a proactive agenda for Black people globally (Aldridge and Young 2003). New ancestry DNA supports this work. The emergence of this new data brings with it an opportunity to explore human identity with Africa as the genesis and center of human existence. It supports stories of the two diasporas, the first based on the genesis of human history that refers back to a sub-Saharan Mitochondrial Eve (Lewin 1987) and the second based on centuries of slavery. Both events shaped and reshaped the world and are carried in human genes. Further, some new information suggests an opportunity for a third emergence of Africa economically (Flows 2016).

One challenge to new possibilities is the concern that Africana Studies will become watered down and lose a focused agenda. New directions may also threaten traditional ways of positioning and articulating race. These shifts have already begun. Hirschman and Panther-Yates (2008) were already predicting that due to new DNA data, "we may be witnessing a potential transformation in the way that race and ethnicity are conceived and acted on in the popular consciousness" (p. 64). Africana Studies are in the position to help light the way.

In the DNA Discussion Project, exploration of these issues is facilitated in a straightforward protocol. First, individuals are asked to share what they believe is their racial background, they are then ancestry DNA tested, and finally, guided in a discussion of findings toward new useful narratives. Borrowing from Fisher (1985) and Stone (1988), Lawton and Foeman (2017) highlight the idea that the development of new narratives is key to a new world order. The challenge is to maintain traditional Africana Studies goals while serving a broader audience. Now is the time to begin to reflect on this balance to disrupt the old order and usher in a better one. 


\section{Research Questions}

Overall, in this paper we will consider how new knowledge of the human migration and the affirmation that "we are all Africans," (Wells 2002) bode for the future of Africana Studies. Our most recent cohort of test takers provides insight for understanding. As the jumping off point, we consider the following questions:

1. Does new ancestry data reveal or clarify African narratives that may have been missing or suppressed?

2. What heritage do participants over or under predict?

3. Do participants over predict indigenous American heritage?

4. How is unexpected heritage received?

\section{Methodology}

\subsection{Participants}

Data for this study came from 286 individuals residing in the Mid-Atlantic region of the United States. We used self-report as the basis for racial identity, similar to the US Census (US Census Bureau 2010). Participants ranged from 17 to 80 years old, with $63.3 \%$ of the sample identifying as female. Participants were recruited purposively to represent a range of racial and/or ethnic groupings. Thus, although the study identifies quantitative trends, participants were selected to allow comparative analysis among racial groupings, rather than to represent the general population. We acknowledge the limitations of this approach as well as its necessity. Institutional Review Board approval was obtained for the research protocol, and each person signed informed consent for the project.

\subsection{Procedures}

Each participant was asked to answer a pre-survey either on paper or online. Data was collected over the course of one year. Initially, participants answered a paper version of the pre-survey, but halfway into the data collection period, the survey was migrated to an online version to facilitate easier data collection. Pre-survey questions asked participants how they identified racially, how they identified using census categories, to draw a pie-chart with how they believed their racial breakdown would be (paper) or use sliders to represent what they believed their racial breakdown would be (online), what ancestry would be unexpected in their background, gaps in their family narratives, and how they thought others saw them. DNA samples were then taken and sent to a commercial lab for processing. Ancestry DNA tests were provided to subjects free of charge. After the ancestry results came back to the researchers, these were sent to participants, who were then asked to answer a post-survey. Post-survey questions asked the same questions as the pre-survey, and added a few more, including whether their results came out the way they expected, what results were hard to believe and why, how they reacted to their results, how they might adjust their family narrative, if friends/family might see them differently, and if they will change any behaviors given the new information. Participants that were part of the online sample were excluded from some data analysis involving numerical racial breakdowns due to unforeseen potential priming factors on some questions in the online survey format, which showed up during data analysis.

\section{Results}

In these analyses, the sample of paper respondents will be the only sample used unless otherwise stated. Participants' identified race(s) were drawn from the open-ended questions: (1) "Please tell what you know about your ethnic background."; (2) "If someone were to ask you what your race is, what would your answer be?". All significance tests are two-tailed. 


\subsection{African Narrative Clarity}

Research Question 1 asked, "Does new ancestry data reveal or clarify African narratives that may have been missing or suppressed?" This refers to whether respondents were able to get specificity regarding their African origins. A chi-square test of independence was performed (Table 1) to examine the relation between African ancestry clarified and persons who identify as African. The population was comprised of both the paper and online samples. The relation between these variables was significant, $\chi^{2}=5.519, \mathrm{df}=1, \chi^{2}(1, \mathrm{~N}=286)=5.519, p<0.02$, indicating that persons who identified as African were more likely to find African ancestry clarified. When the paper and online respondents were investigated individually, the same pattern arose; however, there was not enough respondents to achieve statistical significance.

Table 1. Chi-square test and descriptive statistics for African ancestry clarified for people who identify as African vs. Non-African.

\begin{tabular}{ccc}
\hline & \multicolumn{2}{c}{ African Ancestry } \\
\hline Self-identified as & Yes & No \\
African $(\mathrm{n}=55)$ & $42(76.4 \%)$ & $13(23.6 \%)$ \\
Non-African $(\mathrm{n}=231)$ & $137(59.3 \%)$ & $94(40.7 \%)$ \\
\hline
\end{tabular}

Note: Combined online and paper sample. Numbers in parentheses indicate row percentages.

We looked at gender differences in terms of whether respondents reported increased narrative clarity from ancestry data. Among those who identified as African, females were more likely to report narrative clarity regarding their African origins $(80 \%)$, compared to $56 \%$ of males, $\chi^{2}(1, N=54)=7.148$, $p<0.01$.

\subsection{Heritage Prediction}

Research Question 2 asked, "What heritage do participants over or under predict?"

A $t$-test for paired samples was performed (Table 2) to examine the relation between participants' expected DNA heritage and their actual DNA heritage for both African and Non-African samples. Results from the African sample indicate a significant over-prediction of Indigenous American heritage $(\mathrm{M}=7.64, \mathrm{SD}=8.79, t(13)=3.255, p<0.01)$. Results from the African sample also indicate a significant under-prediction of European heritage $(\mathrm{M}=-10.29, \mathrm{SD}=11.49, t(13)=-3.349, p<0.01)$. Results from the African sample did not indicate any significant discrepancy with any other heritage predictions.

Table 2. Summary table on over- or under-prediction of heritage among Africans vs. Non-Africans.

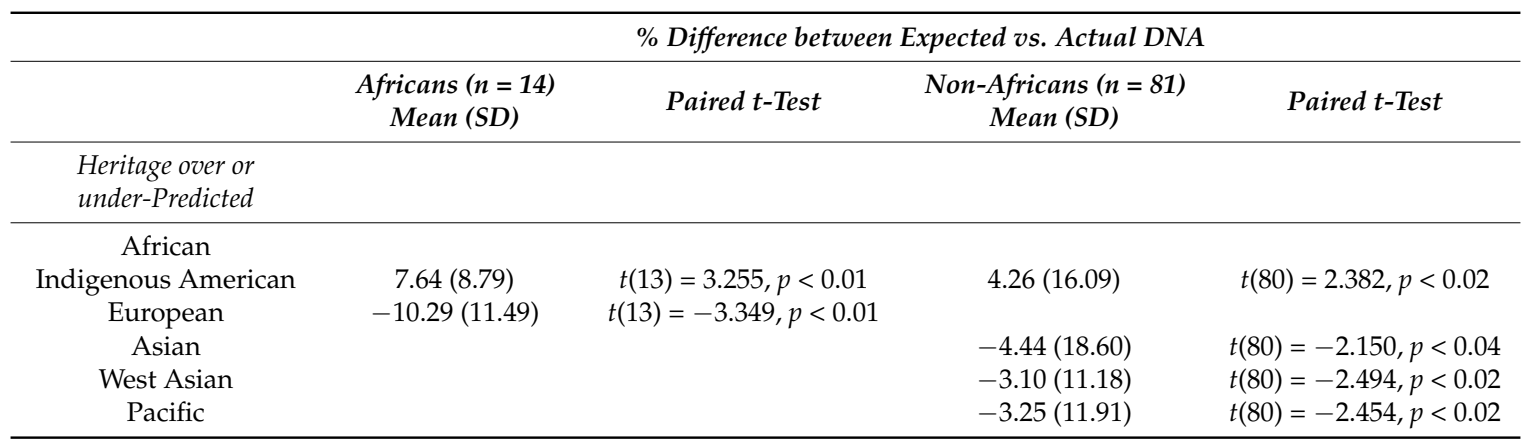

Results from the Non-African sample indicate a significant over-prediction of Indigenous American heritage $(\mathrm{M}=4.26, \mathrm{SD}=16.09, t(80)=2.382, p<0.02)$. Results from the Non-African sample also indicate a significant under-prediction of Asian heritage $(\mathrm{M}=-4.44, \mathrm{SD}=18.60, t(80)=-2.150$, $p<0.04)$; West Asian heritage $(\mathrm{M}=-3.10, \mathrm{SD}=11.18, t(80)=-2.494, p<0.02)$; and Pacific heritage $(\mathrm{M}=-3.25, \mathrm{SD}=11.91, t(80)=-2.454, p<0.02)$. 
To explore these findings more, Table 3 answers Research Question 3, "Do participants over predict indigenous American heritage?" to see if Black and White participants over-predict Indigenous American heritage. The population $(n=267)$ was comprised of both the paper and online respondents. As expected, results indicated a significant over-prediction of Indigenous American heritage for White or Black participants $(\mathrm{M}=6.37, \mathrm{SD}=14.79, t(238)=6.658, p<0.01)$, but for Other races there was no significant difference.

Table 3. Paired $t$-tests on over-estimation of Indigenous American heritage.

\begin{tabular}{cccc}
\hline \multicolumn{4}{c}{ Over-Estimation $(\boldsymbol{n}=\mathbf{2 6 7})$} \\
\hline & Mean Difference & SD & Paired $t$-Test \\
\hline White or Black & 6.37 & 14.79 & $t(238)=6.658, p<0.01$ \\
Other races & 3.63 & 20.73 & $t(29)=0.960, p<\mathrm{ns}$ \\
\hline
\end{tabular}

\subsection{Reactions to Unexpected African DNA}

To examine Research Question 4, which asked "How is unexpected heritage received?", we focused on how Non-African respondents reacted to receiving unexpected African results, since the focus of the paper is on African heritage. Table 4 lists the open-ended responses.

Table 4. Reactions among Non-African respondents who received unexpected African results.

\begin{tabular}{cc}
\hline Reactions $(\mathbf{n}=\mathbf{8 5})$ & $\mathbf{\%}$ \\
\hline Shocked & 50.0 \\
Curious & 42.3 \\
Excited & 34.5 \\
Happy & 19.2 \\
Satisfied & 7.8 \\
Cool & 4.0 \\
Puzzled & 3.9 \\
Positive affect $^{+}$ & 53.4 \\
\hline
\end{tabular}

Data revealed gender and age differences in reactions among Non-African respondents who received unexpected African results. In terms of gender, $43 \%$ of females reported being excited about finding new African DNA their results, vs. $10 \%$ of males, $\chi^{2}(1, N=72)=11.57, p<0.01$. Age was negatively correlated with reported excitement of discovering new African DNA $(r(72)=-0.273$, $p<0.02$ ), which meant that younger people were more excited about finding new African DNA.

Among those who did not find new African DNA, age was negatively correlated with reported shock in not discovering African DNA $(r(205)=-0.154, p<0.03)$, but was positively correlated with reported curiosity $(r(205)=0.195, p<0.01)$. This meant that younger people were more shocked, but older people were more curious, about not finding African DNA.

\section{Discussion}

Our first research question asked whether ancestry data clarified African narratives that may have been suppressed. Results indicate that DNA data does reveal and clarify specific African ancestry both for Black/African identified individuals and for non-Black/African identified individuals, with a stronger effect for those identifying as of African heritage. This makes sense, because still relatively little is known about the great diversity of African cultures on the continent of Africa specifically and among the diaspora in general. Interest has not been overwhelming in filling this intellectual gap, especially about the continent. However, as more and more people take ancestry DNA tests, that gap in knowledge is likely to become of more concern and interest. The implication of this for Pan African 
studies is significant. As more people from all backgrounds express interest and inquire into their African heritage, they will turn to those who have studied these cultures for decades.

Staying in front of the curve can allow scholars in this area to take leadership in guiding the conversation, even among DNA companies that are just beginning to identify African ethnic groups. Professionals like biologist Rick Kittles—owner of Africa Ancestry, Inc. (Washington, DC, USA)—are the exception in this area. Other scholars and leaders will surely be called upon for information and perspective.

New data are being discovered regularly regarding early migration between Africa in and out of Europe, the Middle East, and Asia (Cruciani et al. 2002; Callaway 2015) that provide insight to traditions and histories, language patterns, foods, and phenotypes among black people in the USA and worldwide. New genetic information is a pathway to understanding what is squarely in the area of Pan African studies and makes the future exciting for all.

A deeper understanding of the continent helps people to know Africa and her offspring beyond the singular slave narrative. People can come to view the continent more broadly and accurately, informing the understanding of the historical human migration and modern Africa and African culture worldwide. Exploring histories of the gold coast, east, south, and north Africa helps to educate the uninformed treatment of Africa as a vague monolith. This can help us to explore other variations that are similarly unclear to people in the USA, like the diversity in Middle East, Asia, and among Indigenous Americans. Further, the understanding and respect of cultural variants resist Western hegemony, guiding us to learn to live with ambiguity and complexity and value cultural differences. Africana Studies have always been poised for this leadership, and can have a new and expanded role moving forward.

In answering the second research question (what heritage do participants over or under predict), data reflect that Black participants (African-identified individuals) tend to over-predict Native American ancestry and under-predict European ancestry. Whites (European-identified individuals) overestimate Native American Ancestry. This tends to reinforce a dynamic between these two groups worthy of examination. It also sheds light on the fact that Latinos-often viewed as aliens-tend to have the most indigenous ancestry. Additionally, DNA results show that Asians do not over-predict Native Ancestry, but they do sometimes show trace amounts of Native American ancestry due to migration patterns. The implication of the patterns between Blacks and Whites is considered in the next section. The findings have implications for Africana Studies.

Research Question 3 focused on over-prediction of Indigenous American heritage. The finding that both Whites and Blacks overestimate their indigenous American ancestry is probably associated with a number of factors. First, the history between Whites and Blacks is fraught, so it is not a surprise that both might prefer to replace the other's ancestry with a more palatable narrative. Second, as highlighted in the discussion of Research Question 2, since little is known about African roots, African Americans may replace a lost indigenous African narrative with an indigenous American one. Both Whites and Blacks tend to have romantic Native American narratives not generally related to today's Native Americans. In fact, Whites and Blacks who can claim some connection to indigenous Americas often find that Native Americans are not welcoming. In earlier research, Lawton and Foeman (2017) found that some dark-skinned biracial people were not accepted in Native groups due to their skin color.

A third reason for the overestimation of Native American ancestry might be that people want a claim on this country that is indisputable. Indeed, if a person feels like an American they may not distinguish between a genetic American or a person with American citizenship. In fact, we had to clarify for pre-survey takers that American meant indigenous American. Narrative is so powerful that people may not distinguish between narrative and genetic realities. Fisher (1987) discusses unique narrative proof, disconnected from genetic proof, and based on social constraints rather than physical ones. Foeman, Lawton, and Rieger (Foeman et al. 2014) found that people regularly rejected new DNA data for a lifelong narrative when the information clashed. 
Challenging narrative proof may challenge people's sense of ownership and create dissonance. Indeed, some people are upset when they do not find the Native American ancestry they were looking and hoping for. These conversations could definitely take place in the context of Africana Studies, and knowledge about pattern of contact and identification can add to our learning.

Related to the overestimation of Native ancestry is the finding that African Americans tend to underestimate their European ancestry. Part of this is explained by attitudes about Whites and the negative history between Whites and Blacks. Part is related to idealistic images of Native Americans. Additionally, however, hypodescent leads people to overestimate the "power" of African genes. When one drop of African blood is enough to shape the trajectory of one's entire life, it is difficult, on some level, not to believe that those genes take over one's genome. This psychology speaks to the power of a narrative to structure identity and to consolidate wealth among the minority (Whites) with the participation of racial insiders and outsiders-both of whom have a stake in owning or disowning people of mixed heritage. Thus, it came as a surprise to many African Americans just how much European ancestry they have. It remains to be explored what cultural information is missed in the oversimplification of race. Unpacking this puzzle is challenging to our traditional views of race, but is an important academic endeavor. It is one that is relevant for Africana Studies.

Since many gene variants associated with White phenotype (light hair and eyes) are recessive, and since, in the past, any hint of African ancestry led one (even dark Italians, Indians, and Middle Eastern people, for example) to be identified as non-White, European genetic profiles do tend to be more European overall. Still, tales of "passing" are replete in society, and Whites were aware that a small percentage of African ancestry suggests Black relatives. They responded in a variety of ways, all of which are important to people who study African people and culture.

It is certain that ancestry DNA disabuses us of the notion that narrative proof is the same as genetic reality. New science brings old realities to light. New ancestry DNA is likely to lessen the psychological space between Blacks and Whites, sometimes described as opposites. As narratives of the overlap between racial groups becomes an inherent part of the cultural conscience, even more attention will come to formerly unexplored elements of our backgrounds.

Finally, we comment on the open-ended responses in reaction to African ancestry. One typical reaction to finding African ancestry in a profile that was predicted to be 99 or 100\% European was, "Can I get a scholarship?" However, beyond this narrow perceived benefit is the possibility for a more substantive reaction found in the current research.

In response to the open-ended question asking for three words to describe their reaction to unexpected heritage (in this case African), the most common response was "shock." Despite centuries of living side-by-side, individuals had no personal family narratives to explain possible Black ancestry (on the other hand, they did have narratives to explain nonexistent Native American ancestry). Shock suggests a kind of denial or apprehension of this aspect. It implies that Black ancestry is still perceived by many as undesirable.

The "shock" reaction was followed by "curious." This reaction (along with puzzled) is more ambiguous. Curious was followed by excited, happy, satisfied, and cool, all decidedly positive. Additionally, some people who had no unexpected ancestries expressed that they were disappointed.

When we break the sample into sub-groups, demographic differences in reactions to finding new African DNA are informative. In previous research, Lawton and Foeman (2017) found that females and younger generations tend to have more fluid identifications, and are more willing to adjust racial identification than males and older respondents. Findings in this study are consistent with this, such that females and younger respondents are more likely to be excited about finding new African genetic information. Younger people are also more likely to be shocked if they do not have African DNA. This reflects a shift in how the US is moving toward a more multicultural reality, as evidenced not only in the increase in interracial marriages and more positive attitudes toward this phenomenon (Wang 2012), but also in calls for the Census and many forms with racial questions to offer options that fit the growing multiracial population. 
The range of reaction certainly creates an opening for new information and discussion. The data and reactions to it generate questions about the relationship between race and culture and the idea of cultural/racial authenticity, all relevant to the study of African history and people. Who can claim African ancestry? What does it mean to be Black? Can this identity be imposed externally? Can it be claimed independently?

It can be easy to dismiss new claims, and even to find them superficial, irrelevant, and offensive (i.e., it is cool to be a little black). It is easy to be fearful that such musings can dilute a rigorous discussion of race in America. Yet, these claims are already making their way into the cultural conversation. Reaching out to people who are newly aware of African ancestors and exploration of how ancestors who passed in order to give their progeny (them) a better life is a very personal way to discuss racism. Other hidden ancestries help make the point. There are people with European Jewish ancestry that has gone unacknowledged as well as other ethnic backgrounds that have been deemed undesirable over time.

In addition to ongoing conversations about race, there are discussions about race and genetics that are fascinating, new, inclusive, and awe-inspiring (about genetic complexity and cultural influences) that most people of all backgrounds need to be exposed to. Perhaps we talk too little about them in the context of the discussion of race. It behooves people who are specialists in African Studies to cover it all. It is also their responsibility to ensure that none of it is trivialized.

The Western conception of history tends to move from war to war; as Winston Churchill said, "History is written by the victors." Africana studies has a unique tradition and opportunity to engage people in a different way. By linking the discussion of history to genetic patters and ancestries, the focus is on human normalcy rather than a cycle of war and oppression (although this story is also written in our genes). From this point of view, human variation is normal and desired-it is what has led to our survival, and it is worth preserving. New genetics information places the African experience as the alpha expedience in this story. Further, the African diaspora, based on-among other things-three centuries of systematic dispersal of Black human beings that created the possibility of Western wealth, is a story reinforced by new genetics. Scholars of African history and culture can help inform new insights in new visionary leadership.

The opportunity is a call to invite people to this discussion and take advantage of a drift toward interest and engagement. This calls for scholars to be bold and visionary enough to move African studies to the center of academic inquiry.

If having even a small amount of African ancestry can give people permission to expand their interest, new interest in Africana studies may emerge. One concern, however, is that Africana studies have traditionally been a place of safety for people of African descent to explore African culture on their own terms and outside of the White gaze. Naturally, a shift in focus challenges this safe space.

At the same time, we must consider that the African story is human history and we share more than we differ. The future of Africana Studies in the face of new ancestry information is likely to be different. It is potentially great and exciting with a lifetime of data to unearth as African studies moves from the margins to the center. It is important that people who have guided this field benefit from and contribute to a shift in educational perspectives across academic fields.

Overall, new ancestry data does reveal and clarify African narratives across races. The information provides access to racial history that may have been missing or suppressed. White and Black participants in this research tended to overestimate Native American heritage and African Americans tended to underestimate their European ancestry, all of which reflect on past history. Unexpected African heritage is received with some tentativeness and suspicion, but also with interest and excitement. Taken together, new ancestry DNA data creates an opening to add new information to our understanding and new voices to our discussion. In the process, it is important to ensure that those traditionally leading the call for understanding of the African experience have their voices stay front and center and that the expanded movement does not become academic gentrification of Black 
ideas and research. The call that we are all Africans can be an invitation for marginalized perspectives to move to the center, but not as a sanitized cultural trend.

Author Contributions: Anita Foeman and Bessie L. Lawton conceived and designed the project, and collected the data; Bessie L. Lawton and Nicholas Surdel analyzed the data; all three authors wrote the paper.

Conflicts of Interest: The authors declare no conflicts of interest.

\section{References}

Aldridge, Delores P., and Carlene Young. 2003. Out of the Revolution: The Development of Africana Studies. Lanham: Lexington Books.

Bader, Alyssa C., and Ripan S. Malhi. 2015. Malhi case study on ancestry estimation in an Alaskan Native family: Identity and safeguards against reductionism. Human Biology 87: 338-51. [CrossRef] [PubMed]

Callaway, Ewen. 2015. First Ancient African Genome Reveals Vast Eurasian Migration. Nature. Available online: https: / /www.nature.com/news / first-ancient-african-genome-reveals-vast-eurasian-migration-1. 18531 (accessed on 15 November 2017). [CrossRef]

Craig, Maureen A., and Jennifer A. Richeson. 2012. Coalition or derogation? How perceived discrimination influences intraminority intergroup relations. Journal of Personality and Social Psychology 102: 759-77. [CrossRef] [PubMed]

Cruciani, Fulvio, Piero Santolamazza, Peidong Shen, Vincent Macaulay, Pedro Moral, Antonel Olckers, David Modiano, Susan Holmes, Giovanni Destro-Bisol, Valentina Coia, and et al. 2002. Aback migration from Asia to Sub-Saharan Africa is supported by high-resolution analysis of human Y-chromosome haplotypes. American Journal of Human Genetics 70: 1197-214. [CrossRef] [PubMed]

Fisher, Walter R. 1985. The Narrative Paradigm: In the beginning. Journal of Communication 35: 74-89. [CrossRef]

Fisher, Walter R. 1987. Human Communication as Narration: Toward a Philosophy of Reason, Value, and Action. Columbia: University of South Carolina Press.

Flows, Capital. 2016. U.S. Investors Are Missing out on Africa's Economic Growth. September 21. Available online: https:/ / www.forbes.com/sites/realspin/2016/09/20/bedwetting-u-s-capital-missingout-on-african-growth/\#74d4f5c432a5Foeman (accessed on 20 October 2017).

Foeman, Anita. 2009. Science and magic: Using DNA data to examine the social construction of race. Journal of Intercultural Communication Studies 18: 14-25.

Foeman, Anita. 2012. An intercultural project exploring the relationship among DNA ancestry profiles, family narrative, and the social construction of race. Journal of Negro Education 81: 307-18. [CrossRef]

Foeman, Anita. 2013. Living culture-The social construction of race. In Inter/Cultural Communication: Representation and Construction of Culture. Edited by Anastacia Kurylo. Thousand Oaks: SAGE.

Foeman, Anita, Bessie Lee Lawton, and Randall Rieger. 2014. Ancestry DNA and dialogue on race. Communication Monographs 82: 271-90. [CrossRef]

Girard, Philippe. 2010. Haiti: The Tumultuous History_From Pearl of the Caribbean to Broken Nation. New York: St. Martin's Press.

Golbeck, Natasha, and Wendy D. Roth. 2013. Aboriginal claims: DNA ancestry testing and changing concepts of indigeneity. In Biomapping Indigenous Peoples: Towards an Understanding of the Issues. Edited by Susanne Berthier-Foglar, Sheila Collingwood-Whittick, and Sandrine Tolazzi. New York: Rodopi, pp. 415-32.

Hirschman, Elizabeth C., and Donald Panther-Yates. 2008. Peering inward for ethnic identity: Consumer interpretation of DNA test results. Identity: An International Journal of Theory and Research 8: 47-66. [CrossRef]

Ho, Arnold K., Nour S. Kteily, and Jacqueline M. Chen. 2017. "You're one of us": Black Americans' use of hypodescent and its association with egalitarianism. Journal of Personality and Social Psychology. [CrossRef] [PubMed]

Hochschild, Jennifer L., Vesla M. Weaver, and Traci R. Burch. 2012. Creating a New Racial Order: How Immigration, Multiracialism, Genomics, and the Young Can Remake Race in America. Princeton: Princeton University Press.

Lawton, Bessie, and Anita Foeman. 2017. Shifting winds: Using ancestry DNA to explore multiracial individuals' patterns of articulating racial identity. Identity: International Journal for Theory and Research 17: 69-83. [CrossRef]

Lewin, Roger. 1987. The unmasking of mitochondrial Eve. Science 238: 24-26. [CrossRef] [PubMed] 
Mukherjee, Siddhartha. 2016. The Gene: An Intimate History. New York: Scribner.

Peery, Destiny, and Galen V. Bodenhausen. 2008. Black + White = Black: Hypodescent in reflexive categorization of racially ambiguous faces. Psychological Science 19: 973-77. [CrossRef] [PubMed]

Stone, Elizabeth. 1988. Black Sheep and Kissing Cousins: How Our Family Stories Shape Us. New York: Times Books.

TallBear, Kim. 2013. Native American DNA: Tribal Belonging and the False Promise of Genetic Science. Minneapolis: University of Minnesota Press.

US Census Bureau. 2010. Census Form-Census.gov. Available online: https:/ /www.census.gov/schools/pdf/ 2010form_info.pdf (accessed on 8 October 2017).

Wang, Wendy. 2012. The Rise of Intermarriage/Pew Social \& Demographic Trends. Available online: http: / / www.pewsocialtrends.org/2012/02/16/the-rise-of-intermarriage/ (accessed on 19 November 2017).

Watson, David, and Lee Anna Clark. 1999. The PANAS-X: Manual for the Positive and Negative Affect Schedule-Expanded Form. Ames: The University of Iowa.

Wells, Spencer. 2002. The Journey of Man: A Genetic Odyssey. Princeton: Princeton University Press.

(C) 2018 by the authors. Licensee MDPI, Basel, Switzerland. This article is an open access article distributed under the terms and conditions of the Creative Commons Attribution (CC BY) license (http:/ / creativecommons.org/licenses/by/4.0/). 